\title{
Leadership in Design Management by Prentice Hall's Self-Assessment
}

\author{
Seungpok Choi \\ Interior Design Dept. \\ Silla University, Busan, Korea
}

\begin{abstract}
This paper compares and contrasts four different kinds of leadership models in Design Management. Similarities and differences between these four models in contemporary leadership issues and challenges are analyzed and described. Each model will demonstrate the effects of leadership and how these leaders use the different approaches to develop their leadership style in their design field. This paper proposes that contemporary leadership in Design Management involves a unique bonding among leaders and followers, and more flexible and developed leadership will continue in the understanding and skill with which applying to the dynamic of organization change. The results and application of each model's assessment indicate a team of leaders that are capable of achieving excellence through their combined talents and vision to achieve in design fields using their potential inability of their own leadership.
\end{abstract}

Keywords: Leadership, Self-Assessment, and Design Management.

\section{INTRODUCTION}

Design management is the business part of design. Design management establishes the ongoing processes, business decisions, and strategies that enable innovation and create effectively-designed products, services, communications, environments, and brands that enhance our quality of life and provide organizational success. In other words, design management seeks to link design, innovation, technology, management and customers to supply competitive advantage across the triple bottom line: economic, social/cultural, and environmental factors. It is the art and science of empowering design to enhance cooperation and synergy between both design and business simultaneously to improve design effectiveness. The range of design management from the strategic management of corporate design functions and design agencies, including design operations, staff, methods and processes - to the strategic encouragement of design across the organization as a important differentiator and driver of organizational success. [16] It includes the use of design thinking - or using design processes to solve general business problems. Examples of professionals that are committed design management include design department managers, brand managers, creative directors, design directors, heads of design, design strategists, and design researchers, as well as managers and executives accountable for making decisions about how design is used in the organization (The Design Management Institute, 2009). As leading practitioners of design management and design leadership, leaders are actively engaged in design

\footnotetext{
*Corresponding author.E-mail : sweet@silla.ac.kr Manuscript received Mar. 11, 2010 ; accepted Apr. 13, 2010
}

thinking and managing industrial design, graphic design, service design, environment design, brand identity, interface design, and many other types of design. They need to work for corporations, design agencies, educational institutions, and government.

[16] Design management is the art and science of empowering design to enhance collaboration and synergy between "design" and "business" to improve design effectiveness. Leader in $21^{\text {st }}$ century should have a mission to improve organizations worldwide through the effective integration and management of design and design principles for economic, social and environmental benefit.

This research is focused on effective leadership model in managing design for business success. Topics include design, innovation, design strategy, brand design, design measurements, corporate creativity, and design as management and as leadership. This research has three tier priorities which are design management competency, design management valuation, and effective leadership model in design management for the $21^{\text {st }}$ century.

\section{DESIGN MANAGEMENT VALUATION}

Running a design organization is challenging and takes time, but with the right planning, and a little nurturing and patience, it is not as difficult as it might first appear. The role of the designer has clearly shifted from solving simple problems to solving complex problems, and from working independently in a single-discipline focus to working collaboratively with crossfunctional teams. [17] Thomas (2009) discussed valuation of the design management, and the differences between design 
thinking and design management, and offers some concrete steps that can be taken toward becoming an organization that values and profits from effective design (para. 1).

In Korea, where 95 percent of firms employ fewer than five people, the Korea Design Association has launched an initiative called Designing Demand to help stimulate design-led innovation among the nation's smaller businesses. The Korea government has included the Designing Demand program in its new Solutions for Business portfolio, which brings together a range of supports offered to businesses by government departments, their agencies, and local authorities. The design program introduces experienced designers to smaller companies to mentor them through the process of commissioning, briefing, and managing design. [2] Although the design professionals don't do any resulting design work themselves, they guide the companies toward becoming better clients, investing in design and innovation strategically and managing it effectively. It describes the initiative and offers several case studies as examples of its effectiveness (Antonia, 2009).

\section{PRENTICE HALL'S SELF-ASSESSMENT}

\subsection{Methods and specifications}

Prentice Hall's Self-Assessment Library is a unique learning tool that asses designers' knowledge, beliefs, feelings, and actions in regard to a wide range of personal skills, abilities, and interests. Provided scoring keys allow for immediate, individual analysis. This single volume of fifty-one researchbased instruments is organized into three parts- What About Me? Working with Others, and Life in Organizations-and offers the source from which to learn more about leadership. All self-assessments are focused to help individual better design and manage their work-lives or careers. When designers are on decision making in management, learning about their own decision making style will peak designers interest in the different theories in Self-Assessment and will help them learn and retain the concept by relating it to themselves. Furthermore, Prentice Hall's Self-Assessment enables helping designers to achieve self esteem and even self actualization at work.

I have researched and gathered each typical chosen model as assessment results after reviewing all presented experiment. I first use this assessment tool to analyze the various leadership behaviors and practices of the members of Team. Included in the analysis are each member's team-building quartile percentage, power preference, conflict-handling style, and leadership style. The results of the analysis show why the members of Team work very well together and provide further evidence [14] "Leadership is a social influence process shared among all members of a group. Leadership is not restricted to the influence exerted by someone in a particular position or role; followers are part of the leadership process, too"(Wren, 1995, p. 43). The types of leaders are chosen by each of leaders' various special trait and the following is result data.

After completing this part of the exercise, the participants typically have a new awareness of how several people can look at the different styles and develop widely different interpretations. One or another question can also mean different question to different people.

At this question about organization, I engage the participants in a brief discussion of the critical role played by leaders in creating a sense of shared meaning for key phrases, key concepts, key events, and key images in play within the organization. We all will make inferences; one aspect of leadership concentrates on minimizing our tendency to drift apart in how we assign meaning. The many decisions made by people within an organization will cohere to the extent that they reflect a shared interpretation of what these things mean to us.

\subsection{Assessment Results}

To assess member's individual leadership and team leadership strengths, the members took four self-assessments available through [11] the Pearson Prentice-Hall SelfAssessment Library. The results of each self-assessment are analyzed, and a combined reflection of indications is presented in this section of the paper.

\subsubsection{Question 1: How Good am I at Building and Leading} Teams?

The results of the "How Good am I at Building and Leading Teams?" self-assessment yield team members who demonstrate strong and emerging leadership skills. The self-assessment shows results as groups of scores in quartiles. Strong leadership skills have scores in the first quartile. [11] These scores, 95+ in this category, reflect the dominate ability to organize and lead teams (Pearson Education, Inc., 2007a, para. 2). The second quartile has scores that are between 72-94 (Pearson Education, Inc., 2007a, para. 2). Scores within this quartile indicate that the person has leadership potential but is less dominant. This category suggests there is room for growth.

As shown in Table 1, A and B excel at effective team building and leadership; whereas, $\mathrm{C}$ and $\mathrm{D}$ are in the second quartile, which indicates the ability to be strong leaders and team builders should the need arise. This balances the power and authority of leadership within the team, empowers C and D as viable resources in the team's success and emerging skills for leadership.

Table 1. Pearson Prentice-Hall Self-Assessments How good am I at Building and Leading Teams?

\begin{tabular}{ll}
\hline \multicolumn{1}{c}{ Type } & Score \\
\hline B & 99 \\
D & 76 \\
A & 103 \\
C & 91 \\
\hline
\end{tabular}

$\overline{\text { Note. [11] Scores of } 95 \text { or above are in the top quartile, scores }}$ between 72-94 reflects the second quartile, 60-71 reflect the third quartile, and scores below 60 reflect the fourth quartile (Pearson Prentice-Hall, 2007a, para. 2).

\subsubsection{Question 2: What's My Leadership Style?}

The members participated in a self-assessment of their leadership styles. [11] The objective of this assessment is to determine whether the individual leadership style is people- 
oriented or task-oriented (Pearson Education, Inc., 2007b, para. 1). According to Pearson Education, Inc. (2007b), high scores for task-orientation are scores 10 or above, or low for scores below 10; whereas, high people-orientation scores are scores seven or above, or low for scores below seven (para. 2).

The results of this analysis yield team members that are both people-oriented and task-oriented. As shown in Table 2, C and $\mathrm{D}$ possess a high degree of people-orientation, mixed with a lower degree of task-orientation. B and A's scores, suggest that they are both highly task-oriented and people-oriented.

Table 2. Pearson Prentice-Hall Self-Assessments - What's My Leadership Style?

\begin{tabular}{cccc}
\hline Type & $\begin{array}{c}\text { Concern } \\
\text { People }\end{array}$ & for & $\begin{array}{c}\text { Concern } \\
\text { Task }\end{array}$ \\
\hline B & 10 & 13 \\
D & 8 & 9 \\
A & 11 & 11 \\
C & 9 & 9 \\
\hline
\end{tabular}

Note. [11] Task-oriented scores of 10 or more, refer to a high degree of task-orientation (Pearson Prentice-Hall, 2007b, para. 2). People-oriented scores of seven or more, refer to a high degree of people-orientation (Pearson Prentice-Hall, 2007b, para. 2).

\subsubsection{Question 3: What's My Preferred Conflict Handling Style?}

Conflict in an organization or team can have positive or negative effects on the dynamics of the group, and on the organization. [14] According to Brett, Goldberg, and Ury (1990), conflict is inevitable because of the interplay between "personalities and ideologies," and because of "roles, rules, incentives, and constraints of the organizational structure within which parties interact" (as cited in Wren, 1995, p. 435). [14] If conflicts are not successfully managed, the results will likely be negative; however, successfully managed conflicts, could have a positive impact on the organization as whole. Brett, Goldberg, and Ury (1990), state that "conflict can produce high quality, creative solutions that lead to innovation and progress" when handles successfully (as cited in Wren, 1995, p. 435).

[11] The members assessed their individual conflict handling styles using the Pearson Prentice-Hall "What's My Preferred Conflict Handling Style?" self-assessment. According to Pearson Education, Inc. (2007c), scores yielding higher values in any given category indicate the individual gravitates more toward that behavior when circumstances dictate a response.

Competing. Table 3 shows that members yield low indicators for competing when these scores are set in comparison. These results range from seven to 12 , whereby yielding 12 as the highest indicator. Thus, competition is not a conflict or concern in this team's dynamics of exchange.

Collaborating. Collectively, members yield an average high value of 15 for collaboration, as shown in Table 3. The values for collaboration range from 13-17. This suggests that member recognize the power of collaboration of ideas, brainstorming and positive interactions to succeed as a team.

Avoiding. The behavior of avoiding has a distribution of both high and low indicators. Table 3 shows that D demonstrates a preference for avoidance in matters of conflict. This balances the relationship, but it also creates an awkward balance of power when there is an impasse. Scores range between nine and 19.

Accommodating. The results, as shown in Table 3, yield high indicators among members for accommodating other member's interests in the event of conflicting circumstances. The scores range between 15 and 19 .

Compromising. Table 3 shows that members' compromising results yield high indicators, 16-18, among members for compromising when behaviors present obstacles rather than addressing the pressing issue.

Table 3. Pearson Prentice-Hall Self-Assessments - What's My Preferred Conflict Handling Style?

\begin{tabular}{ccccrc} 
Type & $\begin{array}{l}\text { Compet } \\
\text { ing }\end{array}$ & $\begin{array}{l}\text { Collab } \\
\text { oratig }\end{array}$ & $\begin{array}{c}\text { Avo } \\
\text { iding }\end{array}$ & $\begin{array}{r}\text { Acc } \\
\text { ommo } \\
\text { dating }\end{array}$ & $\begin{array}{c}\text { Co } \\
\text { mpro } \\
\text { mising }\end{array}$ \\
\hline B & 8 & 17 & 9 & 15 & 18 \\
D & 10 & 13 & 19 & 19 & 17 \\
A & 12 & 16 & 9 & 16 & 18 \\
C & 7 & 15 & 11 & 16 & 16
\end{tabular}

Note. [11] The category with the highest score is the respondent's preferred conflict-handling style, and the second highest score reflects the respondent's secondary conflicthandling style (Pearson Prentice-Hall, 2007c, para. 1).

\subsubsection{Question 4: What's My Preferred Form of Power?}

This assessment was an analysis to determine the behaviors leaders use to influence subordinates within the framework of the organization. [11] Leadership power influences followership behavior. The forms of power assessed in the "What's My Preferred Form of Power?" self-assessment, as defined by Hughes, Ginnett, and Curphy (1993), were (1) reward - the ability to distribute valuable rewards; (2) coercive - based on fear; (3) legitimate - based on formal position; (4) expert - possessing knowledge or skill; and (5) referent others desire to identify with the leader (as cited in Wren, 1995, p. 340). This analysis recognizes that the leader's preferred forms of power directly affect follower contributions and responses in the relationship. The higher the value suggests the leaders preferred form of power (Pearson Education, Inc., 2007d, para. 1).

The results of this analysis indicate that referent power is the form of power favored by the members. Scores are consistently high in comparison amongst members, and gravitate upward to five. Coerciveness is the least preferred form of power amongst members. The highest score value for coercive power is 2.5 . Subsequent collaborative scores for expert, legitimate, and reward forms of power are second, third, and fourth choices, respectively. 
Table 4. Pearson Prentice-Hall Self-Assessments - What's My Preferred Form of Power?

\begin{tabular}{|c|c|c|c|c|c|}
\hline Type & $\begin{array}{r}\mathrm{Re} \\
\text { ward }\end{array}$ & $\begin{array}{l}\text { Coe } \\
\text { rcive }\end{array}$ & $\begin{array}{l}\text { Legiti } \\
\text { mate }\end{array}$ & $\begin{array}{l}\text { Exp } \\
\text { ert }\end{array}$ & $\begin{array}{l}\text { Refe } \\
\text { rent }\end{array}$ \\
\hline B & 3.5 & 2 & 3.5 & $\begin{array}{c}4 . \\
5\end{array}$ & 4 \\
\hline D & 3.5 & 2.5 & 4 & 4 & 4 \\
\hline A & 3.5 & 1.5 & 5 & 4.7 & 5 \\
\hline $\mathrm{C}$ & 3.2 & 1 & 3.7 & $\begin{array}{c}4 . \\
5\end{array}$ & 4.7 \\
\hline
\end{tabular}

Note. [11] According to Pearson Education, Inc. (2007d), "A high score (4 or greater) on any of the five dimensions implies that [a subject prefers] to influence others by using that particular form of power (...) [whereas] a low score (2 or less) suggests that [a subject prefers] not to employ this power base (para. 2).

\subsection{Team Leadership Analysis}

Each member's individual scores were analyzed to gain a better understanding of the strengths the member presented to the team. These analyses provided a better understanding of each member's strengths as a leader.

\subsubsection{Type 'B'}

B shows strong tendencies toward the Leader-Member Exchange (LMX) theory of leadership. B's leadership style score showed B was slightly more task-oriented than peopleoriented, 13/10 as shown in Table 2. This score suggests that the goal of the task and the relation between leader and follower were mutually important with slightly more emphasis on the task. [10] According to Nahavandi (2009), the LMX leader establishes a role for the follower, and expects the follower to work hard, be loyal, and supportive of the leader ( $p$. 87).

B's preferred type of power, as shown in Table 4, is strong in both expert and referent, with a slightly higher preference for expert power. [10] Expert and referent powers are reflective of the person not the organization (Nahavandi, 2009, p. 164). Nahavandi (2009) states that in the case of expert power, the leader's expertise, knowledge, and information influence the followers, which makes the followers loyal to the leader because the followers believe in the leader's expertise (p. 165). Referent power refers to the ethical and moral behavior of the leader making the leader respected and liked. [4] Bass (2008) explains that followers want to identify with leaders who have referent power, and followers want to be accepted by the leader (p. 274). Both referent and expert power operate much the same way because of both respect and influence. Both types of power directly affect the design, creating followers that are loyal and supportive of the leader.

B's conflict-handling style is a combination of collaborating, accommodating, and compromising, as shown in Table 3. This combination is indicative of the relation-oriented style. [15] Yukl, (2010) defines relations behavior as consideration, acceptance, and concern for the needs of the followers (p. 76). This type of behavior helps to build and maintain interpersonal relationships between the leader and followers. [15] Yukl (2010) goes on the say that this type of leader behavior creates a friendly working environment that makes it easier to gain cooperation and support from the followers upon which the leader needs to depend to ensure the job done (p. 76). By creating this type of work environment, the leader can expect the followers to work hard because he or she enjoys the rewards of the association with the design leader.

[12] According to Tuckman (1965), every team regardless of the setting must successfully complete a task and at the same time develop interpersonal relations with each team member (as cited in Wren, 1995, p. 355). B's team build skills put B in the upper quadrant, and B's leadership style of task and relational-orientation make for a good team leader further supporting the design style.

\subsubsection{Type 'D'}

D's leadership style is people-oriented. This style of leadership suggests that D prefers personal interactions with followers in an effort to [10] "manage conflicts, train, develop, and motivate followers" (Navahandi, 2006, p. 5). This assessment accurately aligns models of leadership that represent D's charismatic, transformational, and servant leadership styles. [14] People-oriented models like these, manifest to (1) influence and inspire followers; (2) coach and empower followers; and (3) demonstrate servant-leadership actions "to make sure that other people's highest priority needs are being served" (Greenleaf, 1977, as cited in Wren, 1995, p. 22).

D's use of power [10] "depends (...) [to] a great extent on the source and manner in which [she uses] it" (Navahandi, 2006, p. 103). The sources of power, which are most effective, are legitimate power, expert power, and referent power. [10] Yukl and Falbe (1991) state that legitimate power functions when a "legitimate authority source asks the [follower] to do something; [and they] comply with [the] requests and implement decisions" (as cited in Navahandi, 2006, p. 106). D's results indicate that legitimate power, expert power, and referent power share equal positions. Followers are likely to comply with her requests because of legitimate power, but referent power and expert power both contribute to [10] "higher follower satisfaction and performance" (Yukl \& Falbe, 1991, as cited in Navahandi, 2006, p. 108 ). D scored low in both reward and coercive power, which reflects that D prefers not to use of these forms. Subsequently, these positions of power do not align with principles of servant model leadership, and the concept that [8] "acceptance of the person, [may require] tolerance of imperfection" (Greenleaf, 2003, p. 124). D's conflict-handling style has a positive influence on the team performance. Competing with other team members is nonessential, [12] D“[accepts] the group and [accepts the] idiosyncrasies of fellow members" in an effort to foster harmonious relationships (Tuckman, 1995, p. 355). D's scores are indicative of one who avoids conflict, accommodates imperfections, and compromises in decision-making efforts to keep the team functioning in a positive direction. [12] "Harmony is of maximum importance, and task conflicts are avoided to insure harmony". This means putting forth one's best effort so that the team is "labeled as performing" 
(Tuckman, 1995, p. 359).

D's score, as shown in Table 1, for "How Good am I at Building and Leading Teams?" falls in the second quartile. This indicates D's skills for leadership continue to emerge. This influences the team in a positive manner. However, these scores do not reflect the inability to lead. This possibly suggests that D is a passive leader in relation to the use of power. As the need for her expert power and referent power increases, her leadership potential increases.

\subsubsection{Type 'A'}

A shows a strong aptitude for building and leading teams according to the Pearson Prentice-Hall "How Good am I at Building and Leading Teams?" self-assessment. Her score, 103 (shown in Table 1), falls under the first quartile, indicating that she shows a high degree of leadership and team building strength.

According to her results, shown in Table 4, on the Pearson Prentice-Hall "What is My Preferred Type of Power?" selfassessment, A shows an equal preference for legitimate and referent forms of power. However, A shows an aversion to the use of coercive power to motivate followers to comply with requests. Further scores indicate that A may use expert and reward power if the need arises.

[14] According to Hughes, Ginnett, and Curphy (1993), "legitimate power depends on a person's organizational role" (Wren, 1995, p. 342). Referent power, on the other hand, refers to power that has the [14] "potential to influence (...) due to the strength of the relationship between the leader and the followers" (Hughes, Ginnett, \& Curphy, 1993, as cited in Wren, 1995, p. 341). A's equal preference for legitimate and referent powers indicates that she prefers to use her formal authority to incite followers to act upon A's requests as well as relying on her interpersonal relationship with followers to ensure that goals are accomplished.

A's dual preference for legitimate and referent powers correlates well with her equal preference for both task- and people-oriented style of leadership. As shown in Table 2, A scores equally high in relation to her concern for the task, as she does in relation to her concern for people. [14] According to Hersey and Blanchard (n.d.), "[a] follower's effectiveness will ultimately depend on the manner in which the leader applies the appropriate combinations of directive and supportive behaviors" (Wren, 1995, p. 210). The equivalence between task- and people-orientation shown in A's scores may indicate a high ability to adapt well to situational changes in the leader-follower relationship, thus enabling her to apply task-oriented and relations-oriented leader behaviors to meet the needs of differing situations that arise in A's leader-follower relationships.

Leader-follower relationships, and team experiences, are not devoid of conflict. [14] Successful conflict management can bring about positive changes, whereas negative changes result if a team does not successfully manage conflict (Brett, Goldberg, \& Ury, 1990, as cited in Wren, 1995, p. 435). According to A's scores on the Pearson Prentice-Hall "What's My Preferred Conflict Handling Style?" self-assessment shown in Table 3, her preferred conflict handling style is compromise. The compromising style of conflict resolution, [3] "involves give-and-take or sharing whereby both parties give up something to make a mutually acceptable decision. It may mean splitting the difference, exchanging concession, or seeking a quick middle-ground position" (p. 29).

A scored low on avoidance which [3] "may take the form of postponing an issue until a better time, or simply withdrawing from a threatening situation". This indicates that A does not like to resolve conflict by avoiding it. A's results on the conflicthandling style self-assessment show that given a conflict, A will actively seek to resolve the conflict through compromise before attempting to resolve the conflict by any other means. A will also seek to resolve the conflict by any means, rather than avoid the conflict and let it create a negative impact on the team or organization.

\subsubsection{Type 'C'}

C's leadership style is predominately people oriented. The leadership score assessment reveals $\mathrm{C}$ is people orientated and equally task orientated, with both scores being equal at 9 . This combination reveals C's primary concern is for her relationship with team members, and ultimately their success. [4] Bass (1985) suggested that, transformational and transactional leadership augment each other (as cited in Bass \& Stogdill, 1990 , p. 53). As a professional designer, C applies a combination of transactional and transformational leadership and brings this to the learning team environment. Through the application of designing, clients accomplish tasks because designing enables clients to actualize their goals by realizing their strengths and values. Accordingly, $\mathrm{C}$ can identify, respect, and work well with the learning team members strengths.

$\mathrm{C}$ 's highest conflict-handling scores indicate that $\mathrm{C}$ will accommodate, compromise, and collaborate. $\mathrm{C}$ is a good team player, and has learned that each member is vital to the team's success. Designing relies on a direct partnership with a client, and cannot work without a team approach. [4] One can expect that, as Smelser (1961) stated, incongruence between the organization or group members personality and the roles required of them, result in reduced effectiveness (as cited in Bass \& Stogdill, 1990, p. 281). C scored low on competiveness, which makes her less likely to combat a team member and more likely to facilitate the team goals rather than her own.

C scored 91, which placed her in the second quartile of the building and leading a team assessment. This reveals that $\mathrm{C}$ will not be a dominant leader, but would rather empower learning team, and work with them. [4] Bass and Stogdill (1990), state that coaching refers to training that gives guidance and feedback about specific efforts involved in a task, the performance of a job, and the handling of assignments (p. 883). C's score reflect the required qualities in that co-operative control but not dominance is effective to obtain the required results in the learning team partnership.

C's preferred type of power is to rely on what C knows, and the establishment of relationships. C's highest scores reflect the use of both expert and referent power. C's ability to access expert knowledge, yet create a desirable relation of trust, is a requirement of designing and is an asset in a team environment. [14] Hughes, Ginnett, and Curphy (1993) state that expert power is the power of knowledge, and that some people influence others through their relative expertise in particular 
areas (as cited in Wren, p. 342). The referent score (4.7) indicates team members would identify positively with $\mathrm{C}$.

\subsection{Overall Analysis}

Individual style and preferences for handling conflict reflect that the team will put forth every effort to manage conflict effectively. Although competition is not a concern, avoiding conflicting rather than addressing conflict is not an option. The results of this analysis acknowledge that effective conflict management, though important, does not supersede individual skills for demonstrating alternative behaviors of accommodation and compromise. Additionally, collaborative efforts and communicative dialogues effectively move the team in a positive direction.

These results reflect team dynamics that follow the transformational leadership model, with transactional leadership model influences. Subsequently, team members reflect people-oriented skills that give rewards when followership efforts exceed expectations; coach teams; build creative work opportunities; and build trust amongst leadership and followership. Manipulation by coercion is unacceptable, and does not reflect the emotional nature of transformational models and theories. These suggest that as leaders, team members value subordinate contributions such that authority beyond the boundaries of coercion does not necessarily improve follower relationships.

\section{CONCLUSION}

The results of the assessment reveal the leadership style gravitates more toward participative (democratic), with emphasis on authority, accommodation, and collaboration in conflict resolution. In defining and analyzing a team's leadership style in design management, [14] it is important to understand that leadership is a social influence process shared among all members of a group as noted by Hughes, Ginnett, and Curphy (as cited in Wren, 1995, pp. 39-43). Perhaps the greatest revelation of the assessment of typical model is that it reflects the new paradigm of $21^{\text {st }}$ Century leadership in Design Management. Certainly, any one of the team members could lead a team. [14] McFarland, Senn, and Childress (1993), state that everyone can be a leader. In this changing game, sharing leadership and power, like information, is necessary throughout the enterprise (as cited in Wren, p. 459). The members' assessment has the potential to implement a shift toward a more empowering participatory model (Wren, 1995, p. 459). [3] The most important quality of the $21^{\text {st }}$ Century leader needs to be the ability to inspire other people; first pull together in the direction of the vision, and second to do the very best in producing excellent results. The contemporary leadership in Design Management involves a unique bonding among leaders and followers, and more flexible and developed leadership will continue in the understanding and skill with which applying to the dynamic of organization change. The results and application of each model's assessment indicate a team of leaders that are capable of achieving excellence through their combined talents and vision to achieve in design fields using their potential inability of their own leadership.

\section{REFERENCES}

[1] B. J. Avolio, F. J. Yammarino, Transformational and charismatic leadership: The road ahead. San Diego, CA: Emerald, 2002.

[2] W. Antonia, Managing Editor. Managing design in SMEs. DMI Review Article, vol. 20, no.3, 2009.

[3] B. M. Bass, Does the transactional-transformation leadership paradigm transcend organizational boundaries? American Psychologist, vol. 52, no.2, 1997, pp.130-139.

[4] Bass \& Stogdill The Bass handbook of leadership: Theory, research, \& managerial applications (4th ed.). New York: The Free Press, 1990.

[5] J. Chen and C. Silverthorne, Leadership effectiveness, leadership style and employee readiness. Retrieved January 6, 2010, from ProQuest, 2005.

[6] J. G. Clawson, Level three leadership: Getting below the surface. (3rd ed.). Upper Saddle River, NJ: Pearson, 2006.

[7] F. E. Fiedler, A contingency model of leadership, effectiveness, in L. Berkowitz (Ed.), Advances in experimental social psychology. New York: Academic Press, (1), 1964

[8] R. K. Greenleaf, The servant as leader. In Kouzes, J. (2003). Business leadership: A Jossey-Bass reader (pp. 117-136). San Francisco, CA: John Wiley \& Sons, Inc., 1977.

[9] W. Hill, A situational approach to leadership effectiveness. Journal of Applied Psychology, vol. 53, no.6, 1969, pp.513-517.

[10] A. Nahavandi, The art and science of leadership (5th ed.). Upper Saddle River, New Jersey: Pearson Prentice Hall, 2009.

[11] Pearson Education, Inc. How good am I at building and leading a team [Online self-assessment]? Pearson Prentice-Hall Self-assessment library. Upper Saddle River, New Jersey: Pearson Prentice Hall, 2007.

[12] Bruce W. Tuckman, Development Sequence in Small Groups. Psychological Bulletin vol.63, no.6, 1995.

[13] K. Strang, Examining effective and ineffective transformational project leadership. Team Performance Management, vol.11, no.3/4, 2005, pp.68.

[14] J. T. Wren, The leader's companion: Insights on leadership through the ages. New York: The Free Press, 1995.

[15] G. Yukl, Leadership in organizations (7th ed.). Upper Saddle River, NJ: Pearson, 2010.

[16] The Design Management Institute. Retrieved January 6, 2010, from http://www.dmi.org/dmi/html/aboutdmi/design manageme n.htm, 2009.

[17] L. Thomas, How to become a more design-minded organization. DMI Review Article, vol. 20, no.3, Retrieved January $\quad 8, \quad 2010, \quad$ from ttp://www.dmi.org/dmi/html/publications/journal/fullabstr act_d.jsp?itemID=09203LOC28, 2009. 


\section{Seungpok Choi}

He received the B.F.A., M.S in interior design from Pratt Institute, New York, US in 1995, 1998 respectively and is also continually studying Ph.D. in Management from university of Phoenix, US. Since then, he has been a professor of interior design department at Silla University in Korea. His main research interests include designing theme park and the aging facility, and Design Management. 